SHOCK INITIATION EXPERIMENTS ON THE HMX BASED EXPLOSIVE LX-10 WITH ASSOCIATED IGNITION AND GROWTH MODELING

Kevin S. Vandersall, Craig M. Tarver, Frank Garcia, Paul A. Urtiew, Steven K. Chidester

June 18, 2007

14th American Physical Society Topical Conference on Shock Compression of Condensed Matter Kohala Coast, HI, United States June 24, 2007 through June 29, 2007 
This document was prepared as an account of work sponsored by an agency of the United States Government. Neither the United States Government nor the University of California nor any of their employees, makes any warranty, express or implied, or assumes any legal liability or responsibility for the accuracy, completeness, or usefulness of any information, apparatus, product, or process disclosed, or represents that its use would not infringe privately owned rights. Reference herein to any specific commercial product, process, or service by trade name, trademark, manufacturer, or otherwise, does not necessarily constitute or imply its endorsement, recommendation, or favoring by the United States Government or the University of California. The views and opinions of authors expressed herein do not necessarily state or reflect those of the United States Government or the University of California, and shall not be used for advertising or product endorsement purposes. 


\title{
SHOCK INITIATION EXPERIMENTS ON THE HMX BASED EXPLOSIVE LX-10 WITH ASSOCIATED IGNITION AND GROWTH MODELING
}

\author{
Kevin S. Vandersall, Craig M. Tarver, Frank Garcia, \\ Paul A. Urtiew, and Steven K. Chidester
}

\author{
Energetic Materials Center \\ Lawrence Livermore National Laboratory \\ Livermore, CA 94550
}

\begin{abstract}
Shock initiation experiments on the HMX based explosives LX-10 (95\% HMX, 5\% Viton by weight) and LX-07 (90\% HMX, 10\% Viton by weight) were performed to obtain insitu pressure gauge data, run-distance-to-detonation thresholds, and Ignition and Growth modeling parameters. A $101 \mathrm{~mm}$ diameter propellant driven gas gun was utilized to initiate the explosive samples with manganin piezoresistive pressure gauge packages placed between sample slices. The run-distance-to-detonation points on the Pop-plot for these experiments and prior experiments on another HMX based explosive LX-04 (85\% HMX, 15\% Viton by weight) will be shown, discussed, and compared as a function of the binder content. This parameter set will provide additional information to ensure accurate code predictions for safety scenarios involving HMX explosives with different percent binder content additions.
\end{abstract}

Keywords: Explosive, HMX, LX-10, shock to detonation transition, ignition and growth PACS: $82.33 . \mathrm{Vx}, 82.40 . \mathrm{Fp}$

\section{INTRODUCTION}

The shock initiation of HMX (octahydro1,3,5,7-tetranitro-1,3,5,7-tetrazocine) explosives has a wide interest due to general safety concerns. Prior experiments on LX-10 (95\% HMX, 5\% Viton by weight) have been performed [1,2], but the pressure regime of these experiments was limited and questions existed on the extrapolation to lower pressures. Other HMX explosives have also been studied [3] including some common explosives such as PBX 9501 [4,5] and LX-04 [6,7] using wedge tests, electromagnetic velocity gauges, manganin gauges at ambient and elevated temperatures. In this work, the shock sensitivity of LX-10 was measured using in-situ pressure gauges and modeled using Ignition and Growth.

\section{EXPERIMENTAL PROCEDURE}

Shock initiation experiments were performed on the explosive HMX based explosive LX-10 using the $101 \mathrm{~mm}$ diameter propellant driven gas gun at Lawrence Livermore National Laboratory (LLNL). Figure 1 shows a description of a typical experiment. The projectile consisted of a polycarbonate sabot with a 6061-T6 Aluminum flyer plate on the impact surface. As seen in Figure 1, the target 
includes buffer plates in contact with the high explosive at both the front and rear of the assembly to hold the material in place and sandwich the nichrome heater foils. The explosive was in the form of thin disks (with starting density approximately $1.82 \mathrm{~g} / \mathrm{cm}^{3}$ ) with gauge packages inserted in between with the total explosive thickness being $20 \mathrm{~mm}$. The manganin piezoresistive foil pressure gauges placed within the explosive sample were "armored" with sheets of Teflon insulation on each side of the gauge. Manganin is a coppermanganese alloy that changes electrical resistance with pressure (i.e. piezoresistive). Also used were PZT Crystal pins to measure the projectile velocity and tilt (planarity of impact). During the experiment, oscilloscopes measure change of voltage as result of resistance change in the gauges which were then converted to pressure using the hysteresis corrected calibration curve published elsewhere $[8,9]$.

From the data of the shock arrival times of the gauge locations, a plot of distance vs. time ("x-t plot") is constructed with the slope of the plotted lines yielding the shock velocities with two lines apparent, a line for the un-reacted state as it reacts and a line representing the detonation velocity. The intersection of these two lines is taken as the "run-distance-todetonation," which is then plotted on the "PopPlot" showing the run-distance-to-detonation as a function of the input pressure in log-log space.

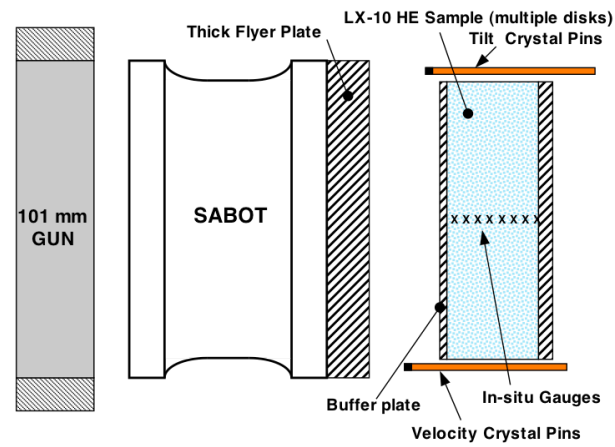

FIGURE 1. Typical description of a shock initiation experiment.

\section{REACTIVE FLOW MODELING}

The Ignition and Growth reactive flow model [10] uses two Jones-Wilkins-Lee (JWL) equations of state, one for the un-reacted explosive and another one for the reaction products, in the form:

$$
p=A e^{-R_{1} V}+B e^{-R_{2} V}+\omega C_{V} T / V
$$

where $\mathrm{p}$ is pressure in Megabars, $\mathrm{V}$ is relative volume, $T$ is temperature, $\omega$ is the Gruneisen coefficient, $\mathrm{C}_{\mathrm{V}}$ is the average heat capacity, and $\mathrm{A}, \mathrm{B}, \mathrm{R}_{1}$ and $\mathrm{R}_{2}$ are constants. The equations of state are fitted to the available shock Hugoniot data. Table 1 contains the modeling parameters and reaction rate constants for these experiments. The reaction rate equation is:

$$
\begin{aligned}
& d F / d t=\underbrace{I(1-F)^{b}\left(\rho / \rho_{0}-1-a\right)^{x}}_{0<F<F_{I_{\max }}}+ \\
& \underbrace{G_{1}(1-F)^{c} F^{d} p^{y}}_{0<F<F_{G_{1} \max }}+\underbrace{G_{2}(1-F)^{e} F^{g} p^{z}}_{F_{G_{2} \min }<F<1}
\end{aligned}
$$

Table 1. Ignition and Growth modeling parameters.

\begin{tabular}{|c|c|}
\hline \multicolumn{2}{|c|}{ MATERIAL PARAMETERS } \\
\hline Shear Modulus $=0.05 \mathrm{Mbar}$ & $\begin{array}{c}\text { Yield Strength }=0.002 \\
\text { Mbar }\end{array}$ \\
\hline$\rho_{0}=1.862 \mathrm{~g} / \mathrm{cm}^{3}$ & $\mathrm{~T}_{\mathrm{O}}=298^{\circ} \mathrm{K}$ \\
\hline \multicolumn{2}{|c|}{ REACTION RATES } \\
\hline $\mathrm{a}=0.0794$ & $\mathrm{x}=4.0$ \\
\hline $\mathrm{b}=0.667$ & $\mathrm{y}=2.0$ \\
\hline $\mathrm{c}=0.667$ & $\mathrm{z}=3.0$ \\
\hline $\mathrm{d}=0.667$ & $\mathrm{~F}_{\text {igmax }}=0.02$ \\
\hline $\mathrm{e}=0.333$ & $\mathrm{~F}_{\mathrm{G} 1 \mathrm{max}^{-}=0.5}$ \\
\hline $\mathrm{g}=1.0$ & $\mathrm{~F}_{\mathrm{G} 2 \mathrm{~min}=0.5}$ \\
\hline $\mathrm{I}=20000 \mu \mathrm{s}^{-1}$ & $\mathrm{G}_{1}=250 \mathrm{Mbar}^{-2} \mu \mathrm{s}^{-1}$ \\
\hline- & $\mathrm{G}_{2}=320 \mathrm{Mbar}^{-2} \mu \mathrm{s}^{-1}$ \\
\hline
\end{tabular}

Table 2. Gruneisen parameters for inert materials.

\begin{tabular}{|c|c|c|c|c|c|c|c|}
\hline INERT & $\begin{array}{c}\rho_{0} \\
(\mathrm{~g} / \mathrm{cc})\end{array}$ & $\begin{array}{c}\mathrm{C} \\
(\mathrm{km} / \mathrm{s})\end{array}$ & $\mathrm{S}_{1}$ & $\mathrm{~S}_{2}$ & $\mathrm{~S}_{3}$ & $\gamma_{0}$ & $\mathrm{a}$ \\
\hline $\begin{array}{l}\text { 6061- } \\
\text { T6 Al }\end{array}$ & 2.703 & 5.24 & 1.4 & 0.0 & 0.0 & 1.97 & 0.48 \\
\hline Teflon & 2.15 & 1.68 & 1.123 & 3.98 & -5.8 & 0.59 & 0.0 \\
\hline
\end{tabular}


where $\mathrm{F}$ is the fraction reacted, $\mathrm{t}$ is time in $\mu \mathrm{s}, \rho$ is the current density in $\mathrm{g} / \mathrm{cm}^{3}, \rho_{\mathrm{O}}$ is the initial density (calculated based on thermal expansion data), $p$ is pressure in Mbars, and $I, G_{1}, G_{2}$, a, $\mathrm{b}, \mathrm{c}, \mathrm{d}, \mathrm{e}, \mathrm{g}, \mathrm{x}, \mathrm{y}$, and $\mathrm{z}$ are constants. This reaction rate law models the three stages of reaction generally observed during shock initiation of solid explosives. Table 2 details the Gruneisen parameters used.

\section{RESULTS/DISCUSSION}

Table 3 contains the experimental flyer velocities, impact pressures, and run distances to detonation for the experiments.

Table 3. Summary table of LX-10 gun experiments.

\begin{tabular}{|c|c|c|c|}
\hline SHOT & $\begin{array}{c}\text { IMPACT } \\
\text { VELOCITY }\end{array}$ & $\begin{array}{c}\text { INPUT } \\
\text { PRESSURE }\end{array}$ & $\begin{array}{c}\text { RUN TO } \\
\text { DET }\end{array}$ \\
\hline 4714 & $0.732 \mathrm{~km} / \mathrm{s}$ & $2.1 \mathrm{GPa}$ & $>29 \mathrm{~mm}$ \\
\hline 4715 & $0.981 \mathrm{~km} / \mathrm{s}$ & $3.1 \mathrm{GPa}$ & $14.4 \mathrm{~mm}$ \\
\hline 4717 & $0.625 \mathrm{~km} / \mathrm{s}$ & $1.7 \mathrm{GPa}$ & $>40 \mathrm{~mm}$ \\
\hline 4723 & $1.238 \mathrm{~km} / \mathrm{s}$ & $7.0 \mathrm{GPa}$ & $2.7 \mathrm{~mm}$ \\
\hline 4725 & $0.950 \mathrm{~km} / \mathrm{s}$ & $4.8 \mathrm{GPa}$ & $6.7 \mathrm{~mm}$ \\
\hline 4726 & $0.943 \mathrm{~km} / \mathrm{s}$ & $2.9 \mathrm{GPa}$ & $20.5 \mathrm{~mm}$ \\
\hline 4727 & $0.733 \mathrm{~km} / \mathrm{s}$ & $2.1 \mathrm{GPa}$ & $30.8 \mathrm{~mm}$ \\
\hline
\end{tabular}

The resulting data points are plotted on the Pop-plot as shown in Figure 2. The in-situ gauge records are shown compared with the modeling results in Figures 3-5 that span a range of run distances to detonation. An increase in pressure can be observed as the shock progresses through and reacts the explosive material until a full detonation is observed. From comparing these records a somewhat reasonable agreement can be seen with room for improvement in the fit. The wave arrival times for the model arrive earlier than the data, especially for the lower pressures.

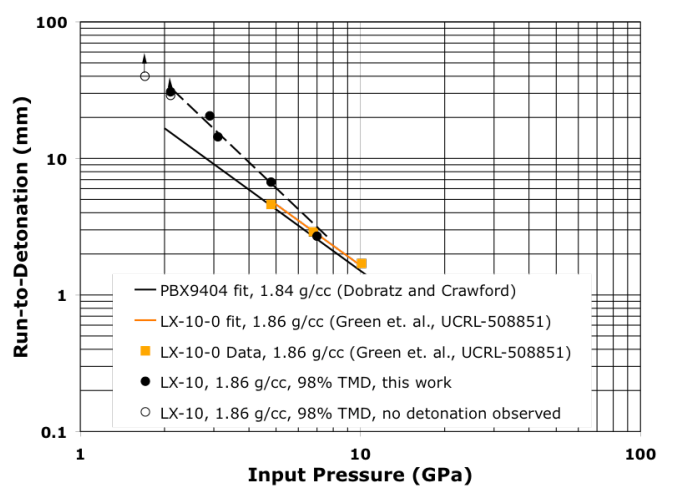

FIGURE 2. Pop-Plot comparing the data from this work with that of previous experiments.

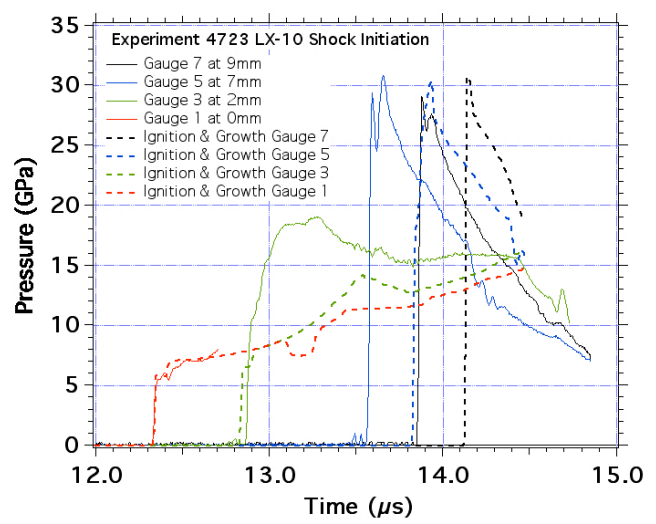

FIGURE 3. Experimental and calculated pressure histories for experiment 4723 .

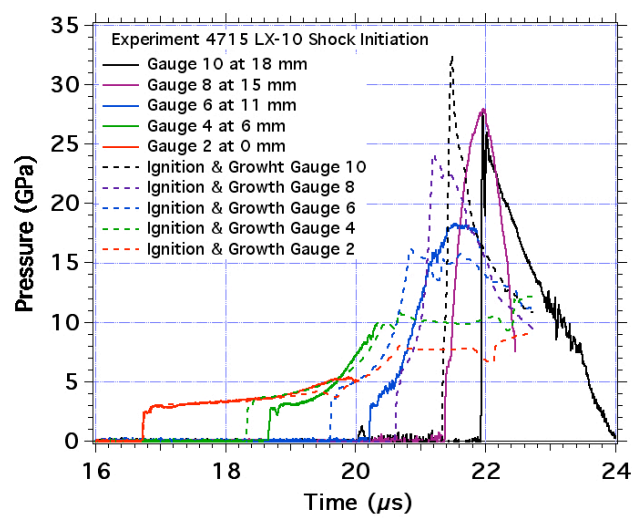

FIGURE 4. Experiment and calculated pressure histories for experiment 4715 . 


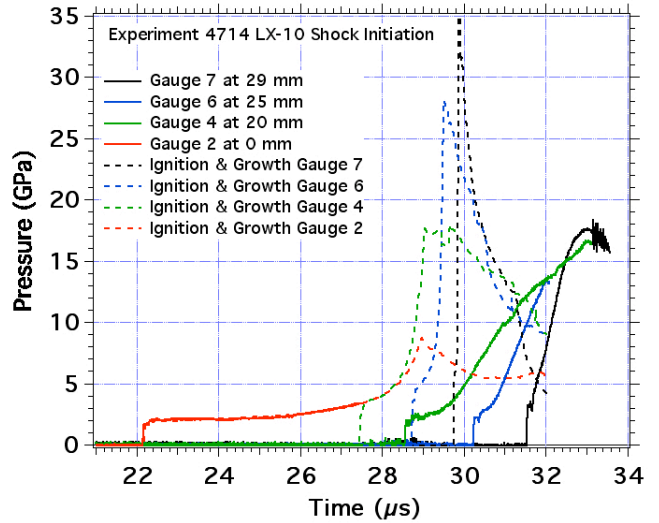

FIGURE 5. Experimental and calculated pressure histories for experiment 4714.

\section{SUMMARY}

Shock initiation experiments on the HMX based explosives LX-10 (95\% HMX, 5\% Viton by weight) was performed to obtain in-situ pressure gauge data, run-distance-to-detonation thresholds, and Ignition and Growth modeling parameters. The modeling fits showed somewhat reasonable agreement to the experimental data with room for improvement. Future work is needed to adjust the model to obtain a better fit to the data.

\section{ACKNOWLEDGEMENTS}

Special thanks go to the $101 \mathrm{~mm}$ gun crew in the High Explosives Application Facility (HEAF) including Rich Villafana, Steve Kenitzer, and Bradley Wong. This work was performed under the auspices of the U. S. Department of Energy by the University of California, Lawrence Livermore National Laboratory under Contract No. W-7405Eng-48.

\section{REFERENCES}

1. Craig M. Tarver, Paul A. Urtiew, Steven K. Chidester, and LeRoy G. Green, "Shock Compression and Initiation of LX-10," Propellants, Explosives, Pyrotechnics, 18, 117127 (1993).
2. Green, L. G., Wasley, R. J., Kramer, P. E., "Shock Initiation of LX-07-02 and LX-10-0," LLNL Report No. UCRL-50851, 1970.

3. LASL Explosive Property Data, Terry R. Gibbs and Alphonse Popolato, Editors, University of California Press, pp. 353-358, 1980.

4. Gustavsen, R. L., Sheffield, S. A., Alcon, R. R., and Hill, L. G., "Shock Initiation of New and Aged PBX 9501," Proceedings of the $12^{\text {th }}$ International Symposium on Detonation, San Diego, CA, August, 2002, pp. 530-537.

5. Kevin S. Vandersall, Craig M. Tarver, Frank Garcia, and Paul A. Urtiew, "Shock Initiation Experiments on PBX 9501 Explosive at $150^{\circ} \mathrm{C}$ for Ignition and Growth Modeling," Shock Compression of Condensed Matter - 2005, AIP Conference Proceedings 845, Baltimore Maryland, 2006, pp. 1127-1130.

6. Kevin S. Vandersall, Craig M. Tarver, Frank Garcia, Steven K. Chidester, Paul A. Urtiew and Jerry W. Forbes, "Low Amplitude Single and Multiple Shock Initiation Experiments and Modeling of LX-04," 13th International Detonation Symposium, Norfolk, VA, July 23 28, 2006, in press

7. Urtiew, P. A., Forbes, J. W., Tarver, C. M., Vandersall, K. S., Garcia, F., Greenwood, D. W., Hsu, P. C., and Maienschein, J. L., "Shock Sensitivity of LX-04 with Delta Phase HMX at Elevated Temperatures," Shock Compression of Condensed Matter - 2003, pp. 1053-1056.

8. Vantine, H.C., Erickson, L.M. and Janzen, J., "Hysteresis-Corrected Calibration of Manganin under Shock Loading", J. Appl. Phys., 51 (4), April 1980.

9. Vantine H., Chan J., Erickson L. M., Janzen J., Lee R. and Weingart R. C., "Precision Stress Measurements in Severe Shock-Wave Environments with Low Impedance Manganin Gauges," Rev. Sci. Instr., 51. pp. 116-122 (1980).

10. Tarver, C. M., Hallquist, J. O., and Erikson, L. M., "Modeling Short Pulse Duration Shock Initiation of Solid Explosives," Eighth Symposium (International) on Detonation, Naval Surface Weapons Center NSWC MP86194, Albuquerque, NM, 1985, pp. 951-961. 